\title{
Turizm Eğitimi Alan Lisans Öğrencilerinin Öz Yeterliklerinin Akademik Başarı ve Bireysel Özellikler Açısından İncelenmesi
}

\author{
Examination of the Self-Efficacy of Undergraduate Students in Tourism \\ Education in terms of Academic Achievement and Individual Characteristics
}

\author{
Dr. Öğr. Üyesi Murat KIZANLIKLI ${ }^{1}$, Arş. Gör. Dr. Cemal Ersin SİLIK ${ }^{2}$
}

\begin{abstract}
Özet
$\mathrm{Bu}$ araştırmanın amacı, turizm eğitimi almakta olan lisans öğrencilerinin öz yeterlik algılarının bireysel özelliklerine ve akademik başarı düzeylerine göre farklılık gösterip göstermediğini tespit etmektir. Veri toplama aracı olarak anket formu kullanılmıştır. Öğrencilerin öz yeterlik düzeylerini ölçmek için Sherer vd. (1982) tarafindan geliştirilen ve Yıldırım ve İlhan (2010) tarafindan Türkçe geçerlilik ve güvenilirlik çalışması yapılan Genel Öz Yeterlik Ölçeği kullanılmıştır. Araştırmanın evrenini, lisans düzeyinde turizm eğitimi almakta olan öğrenciler oluşturmaktadır. Basit tesadüfi örnekleme yöntemine göre, rastgele seçilen öğrencilerden toplanan 514 adet kullanılabilir anket formu analize tabi tutulmuştur. Verilerin analizinde yüzde ve frekans analizlerinin yanı sıra, araştırma hipotezlerinin test edilmesine yönelik bağımsız örneklemler için $t$ testi ve varyans analizi (Anova) kullanılmıştır. Bulgulara göre, öğrencilerin öz yeterlik düzeylerinin mezun olunan lise, bölüme yerleşme isteği ve herhangi bir öğrenci topluluğuna üye olma durumuna göre anlamlı bir farklılık gösterdiği tespit edilmiştir. Öğrencilerin genel öz yeterlik durumları ile akademik başarı düzeyleri arasında ise anlamlı bir farklılık tespit edilmemiş olmakla birlikte $(p>0,05)$, öz yeterlik toplam değerlerine göre, öğrencilerin akademik başarı düzeyleri yükseldikçe, genel öz yeterlik puanlarının da arttığı dikkat çekmektedir.
\end{abstract}

Anahtar Kelimeler: Öz yeterlik, akademik başarı, turizm eğitimi, bireysel özellikler

Makale Türü: Araştırma makalesi

\begin{abstract}
The purpose of this study is to determine whether the self-efficacy status of undergraduate students who are receiving tourism education differs according to their individual characteristics and academic achievement levels. A questionnaire is used as a data collection instrument. General SelfEfficacy Scale is used which was developed by Sherer et al. (1982) and the validity and reliability in Turkish was tested by Ylldrrm and IIthan (2010), to measure students' self-efficacy levels. The population of the study consists of students who are studying tourism at the undergraduate level. A total of 514 questionnaires were analyzed. In addition to the percentage and frequency analyzes, the hypotheses of the study were tested by using independent samples $t$ test and Anova analysis. According to the study results, it is found that the self-efficacy levels of the participants showed a significant difference according to the graduated high school, the desire to study in the department
\end{abstract}

\footnotetext{
${ }^{1}$ Ankara Hacı Bayram Veli Üniversitesi, Turizm Fakültesi, muratkizanlikli@gazi.edu.tr, Orcid ID: https://orcid.org/00000002-6953-767X

${ }^{2}$ Ankara Hacı Bayram Veli Üniversitesi, Turizm Fakültesi, cemalersin.silik@ gazi.edu.tr, Orcid ID: https://orcid.org/00000001-8662-4188
} 
and the membership status to the student societies. In addition, there is no significant difference between the students' general self-efficacy and academic achievement levels ( $p>0,05)$. However, considering the total self-efficacy values, as the academic achievement levels of students increase, their general self-efficacy scores have also increased.

Key Words: Self-efficacy, academic achievement, tourism education, individual characteristics

Paper Type: Research paper

\section{Giriş}

Davranışı yönlendiren ve düzenleyen süreçleri açıklamaya çalışan farklı teoriler arasında Sosyal Bilişsel Kuram (Bandura, 1977) en önemli teorilerden birisi olarak kabul edilmektedir. Sosyal Bilişsel Kuram; dış sosyal sistemlerin ve içsel öz-etki faktörlerinin bir bileşiminin, davranışları motive edip düzenlediğini öne sürmektedir (Bandura, 2012; Schunk ve Pajares, 2002). Bandura'ya göre (1997) bu öz-etki faktörlerinden öz yeterlik (self efficacy), temel bir bileşendir ve bir bireyin, istenen performansları elde edebilmek için gerekli eylemleri organize etme ve yürütme yeteneklerine yönelik yargısını ifade etmektedir.

Öz yeterlik kuramı, Bandura'nın (1977) sosyal öğrenme kuramından türetilmiş ve bir kişinin belirli bir görevi yerine getirebilme yeteneğine olan inancını ifade etmektedir. Ryan (1970)'a göre, kendini algılama veya bir kişinin kendi yeteneklerini ve eğilimlerini algılayış şekli niyetlerin gelişiminde önemli bir rol oynamaktadır. Buna benzer bir biçimde öz yeterlik, bireyin belirli hedeflere ulaşılıp ulaşmadığına yönelik inançlarını etkilemektedir. Öyle ki, zorluklar karşısındaki seçimler, arzular, çabalar ve sabır, kişinin kendi yeteneklerini algılayışs şekli veya kendini algılama niyetinden etkilenmektedir (Bandura, 1991).

Çalışma kapsamında, öncelikle öz yeterlik kavramı hakkında bilgi verilmiş, öz yeterlik inançlarına yönelik kaynaklar (ustalık deneyimleri, modelleme, sosyal ikna ve fiziksel durum) açıklanmış ve son olarak öz yeterlik ile akademik performans arasındaki ilişkiler üzerine yapılmış çalışmalara yer verilmiştir.

\section{1. Öz Yeterlik Kavramı}

İnsan bilişini, eylemini, motivasyonunu ve duygusunu anlamaya yönelik bir yaklaşım olduğu varsayılan öz yeterlik kavramının, genel olarak "Sosyal Bilişsel Kuram" kapsamında açıklandığı ifade edilmektedir (Bandura, 1997; Barone vd., 1997). Sosyal Bilişsel Kuramın kısaltılmış ve sadeleştirilmiş dört temel dayanağı bulunmaktadır. Bunlar; bireylerin güçlü bilişsel veya simgeleştirme yeteneği, çevresel olaylara bilişsel, etkili ve davranışsal yanıt verme yeteneği, öz ve kişiliğin başkalarıyla etkileşimler sonucunda değişime uğraması ve bireylerin kendi kendini yönetme yeteneğidir (Maddux, 2000: 6).

Öz yeterlik; deneyim yoluyla elde edilen bilişsel, sosyal, dilsel ve/veya fiziksel yeteneklerin gelişmesi ile birlikte yavaş yavaş kazanılır (Bandura, 1982; Gist, 1987). 


\section{Șekil 1. Öz Yeterlik Teorisi}

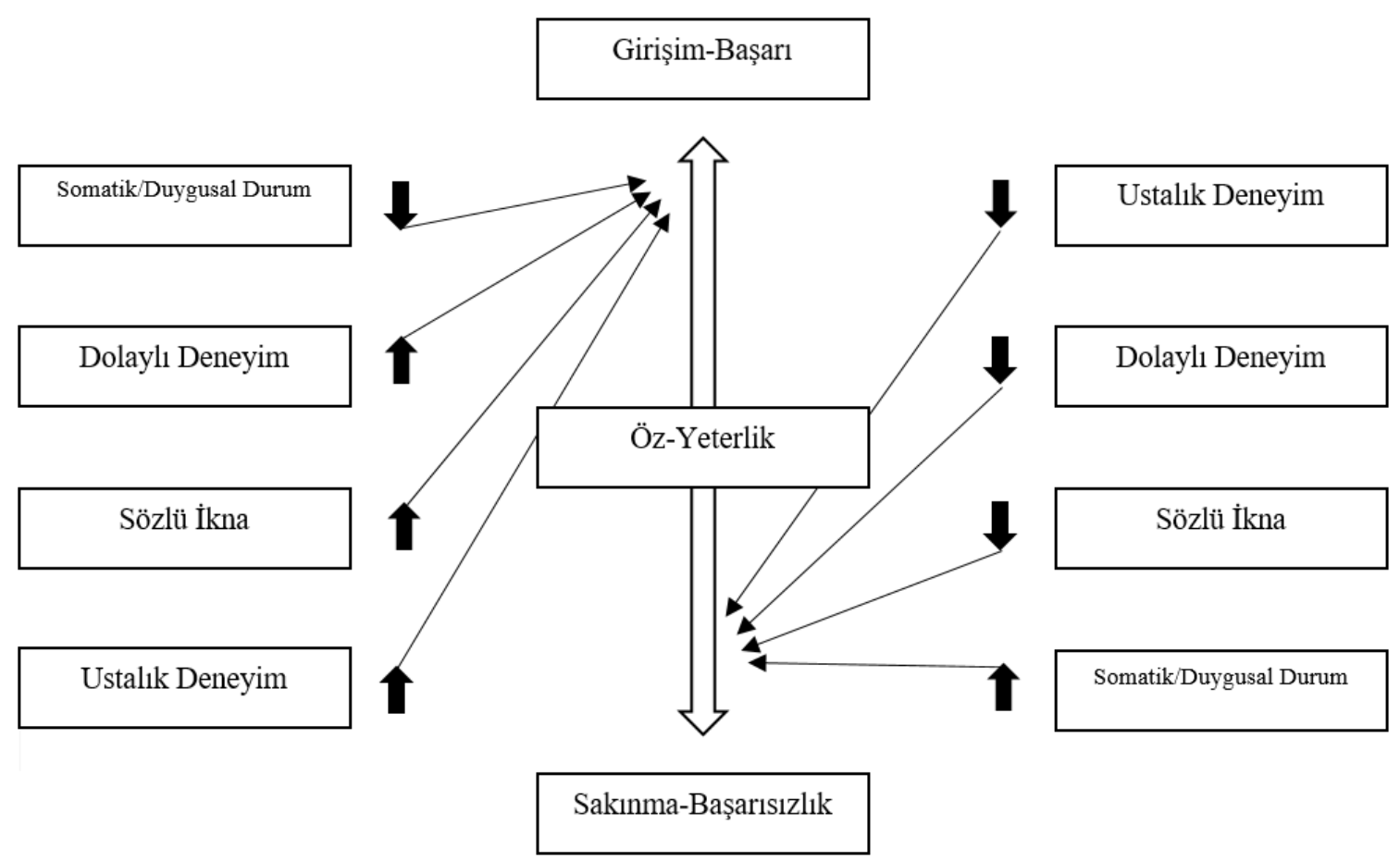

Kaynak: Brown vd., 2013: 22

Şekil 1'de ifade edilen öz yeterlik teorisine göre, somatik/duygusal durum, dolaylı deneyim, sözlü ikna ve ustalık deneyimleri bireylerin öz yeterliklerini ve dolayısıyla da bireylerin davranışlarını etkilemektedir. Şekil 1'e göre; stres ve kaygı düzeyi düşük, olumlu dolaylı deneyimlere, pozitif nasihat ve teşviklere, doğrudan yaşanmış olumlu deneyimlere sahip bireyler, yüksek düzeyde öz yeterliğe sahip olmakla birlikte girişim-başarı davranışları sergilemektedir. Bunun yanında; stres ve kaygı düzeyi yüksek, olumsuz dolaylı deneyimlere, negatif nasihat ve teşviklere, doğrudan yaşanmış olumsuz deneyimlere sahip bireylerin, düşük düzeyde öz yeterliğe sahip olmakla birlikte sakınma-başarısızlık davranışları sergilediği ifade edilmektedir.

Öz yeterlik, algılanan beceriden ziyade, belirli şartlar altında bireylerin becerileri ile yapabileceklerine inanma durumudur. Fakat bu durum, değişen ve zorlayıcı şartlardaki beceri ve yetenekleri koordine etme ve yönetebilme konusundaki inanç ile ilgilidir (Maddux, 2000: 4). Akademik bağlamda ise genellikle öz yeterlik, öğrencinin eğitimsel hedeflerine başarılı bir şekilde ulaşabilmesi için öğrenenin yargılarını tanımlayan akademik öz yeterlik (academic self efficacy) olarak ifade edilmektedir (Elias ve MacDonald, 2007).

Öğrenme ve devamında akademik performans için akademik öz yeterliğin önemini ortaya koyan zengin bir alanyazın bulunmaktadır. Akademik öz yeterlik ve akademik performans arasındaki ilişkiyi belirleyebilmek için ilkokullarda (Joet vd., 2011; Y1lmaz vd., 2012), liselerde (Alivernini ve Lucidi, 2011; Bala vd., 2017) ve üniversitelerde (Robbins vd., 2004; Komarraju ve Nadler, 2013; El-Hmoudova, 2015; Sevilmiş ve Şirin, 2016; Honicke ve 
Broadbent, 2016; Bui vd., 2017; Jung vd., 2017; Tsai vd., 2017) bulunan öğrencilere yönelik öğrenme ortamında bir dizi araştırma yapılmıştır. Ayrıca, akademik öz yeterliğin; cebir veya geometri problemleri gibi konuya özgü işleri başarıla tamamlamada akademik performans üzerindeki etkisini (Zimmerman ve Martinez-Pons, 1990), bir derste özel bir not elde etme veya başarılı bir performans göstermede akademik performans üzerindeki etkisini (Neuville vd., 2007) veya üniversite derslerinde genel başarı sağlamada akademik performans üzerindeki etkisini (Pintrich ve DeGroot, 1990; Cassidy ve Eachus, 2002) ortaya koymaya yönelik çeşitli çalışmalar yapılmıştır (Honicke ve Broadbent, 2016: 64).

Akademik öz yeterlik, akademik başarıyı hem doğrudan hem de dolaylı olarak desteklemekte (Bandura vd., 1996) ve yükseltmektedir. Bununla birlikte yapılan araştırmalarda (Schunk, 1989; Carini vd., 2006; Komarraju ve Nadler, 2013; Jung vd., 2017; Bui vd., 2017) akademik öz yeterlik ile akademik başarı arasında pozitif bir ilişki olduğu ortaya konulmuştur. $\mathrm{Bu}$ nedenle, öz yeterliğin belirli bir kültürel bağlamda ve alan işleyişinde nasıl çalıştığını bilmek, öğrencilerin istenen kişisel değişimlerini gerçekleştirebilmeleri için oldukça önemlidir (Bui vd., 2017).

\section{2. Öz Yeterlik İnançlarına Yönelik Kaynaklar}

Bandura (1977), geliştirdiği teorinin, formları ne olursa olsun psikolojik prosedürlerin, öz yeterliğin gücünü ve düzeyini değiştirdiğini ifade etmektedir. Önerilen modelde kişisel yeterlik beklentilerinin; ustallk deneyimleri, modelleme (gözlemsel öğrenme), sosyal ikna ve bireylerin kendi fiziksel durumlarını göz önünde bulundurması gibi dört temel bilgi kaynağından elde edildiği açıklanmaktadır. Buradan hareketle, bireylerin öz yeterliğe yönelik inançlarını bu dört kaynağa göre geliştirip güçlendirebildikleri ifade edilmektedir (Bandura, 1982; Wood ve Bandura, 1989). Bireylerin performans yargıları ise, bu kaynakların tamamından elde edilen yeterlik bilgilerinin birleşiminden oluşmaktadır (Lent ve Hackett, 1987; Gist ve Mitchell, 1992). Bu nedenle, öz yeterlik oluşumu bireylerin gelecekteki performansını etkileyebilecek hem kişisel hem de durumsal kaynakların ve kısıtlamaların mevcudiyetini değerlendirmesinden de kaynaklanmaktadır (Ajzen, 1987; Gist ve Mitchell, 1992).

\subsection{Ustalık Deneyimleri}

Kişilerin güçlü bir öz yeterlik duygusu geliştirmeleri için en etkili yol, ustalık deneyimleri veya tekrarlanan performans başarılarıdır (Bandura, 1977, 1982; Gist, 1987; Wood ve Bandura, 1989). Bunun yanında performans aksaklıkları, başarı için sürekli bir çabaya ihtiyaç duyulduğunu ortaya koymaktadır. Bu nedenle ustalık deneyimleri, gelecekteki performansın olumlu sonuçlanabilmesi için fikir oluşumu sağlamaktadır (Lent ve Hackett, 1987). Bireylerin başarılarını tecrübe ederek yeteneklerine karşı bir güven duygusu geliştirmesi, başarısızlık veya aksiliklerin daha iyi yönetilmesine yardımcı olmaktadır (Wood ve Bandura, 1989). Güçlü bir öz yeterlik duygusunun oluşabilmesi, kişilerin doğrudan deneyimler yaşaması ile mümkün olabilmektedir. Bu nedenle elde edilecek olumlu deneyimler, ileride yaşanabilecek benzer durumlar için kişilerde öz yeterlik duygusunun gelişimine yardımcı olacaktır (Arseven, 2016: 68). Sonuç olarak, insanların kendi çabaları ile oluşturdukları başarılı deneyimler öz yeterliği güçlendirirken, başarısız deneyimler öz yeterlik duygusunu azaltmaktadır (Maddux, 2000: 8). 


\subsection{Dolaylı Deneyim/Modelleme}

Öz yeterlik inançları, başkalarının davranışlarına ve bu davranışların sonuçlarına ilişkin gözlemlerimiz tarafından da etkilenmektedir (Bandura, 1997). Öz yeterlik inançlarının geliştirilmesinde, ustalık deneyimlerden biraz daha az etkili olan ikinci bir yol dolayl deneyim/modellemedir. Modelleme sürecinde bireyler, görgülü deneyim ya da gözlemsel öğrenme sürecini ortaya koymaktadır (Gist, 1987; Wood ve Bandura, 1989). Yeterli rol modelleri, durumları yönetmek için etkili stratejiler sunmaktadır ve bir sosyal karşılaştırma süreci yoluyla öz yeterliği etkilemektedir (Wood ve Bandura, 1989). Yani, insanlar kendilerini başkalarıyla kıyaslayarak kendi yeteneklerinin yargılarını oluşturmaktadır. Kişiler, kendilerine benzeyen bireylerin zorluklar karşısında başa çıkabilmelerini gözlemleyerek, kendilerinin de aynı yeteneklere sahip oldukları inancını kendisinde oluşturabilir (Arseven, 2016: 68). Modellemenin etkileri, özne ve model arasındaki kişisel özellikler ve yetenekler yönünden algılanan benzerlik olduğunda ve modellenen davranış net sonuçlar oluşturduğunda geliştirilmektedir (Bandura, 1977: 197; Gist, 1987).

\subsection{Sosyal İkna/Sözlü İkna}

Öz yeterliğin güçlendirilebileceği üçüncü bir yol ise sosyal ikna/sözlü ikna yoludur. İkna edici tartışmalar ve özel performans geribildirimi, bir kişinin bir görevi yerine getirme yeteneği ile ilgili bilgi sağlamak için kullanılabilmektedir (Gist ve Mitchell, 1992). Eğer bireyler, bir görevi yerine getirebileceklerini ikna etmeye yönelik olumlu geri bildirim ve gerçekçi teşvik alırsa, daha fazla çaba gösterme eğiliminde olabilmektedir (Gist, 1987; Wood ve Bandura, 1989). Bu yöntemin kullanımındaki en büyük tehlike, öz yeterlik inançlarının gerçekçi olmayan seviyelere yükseltilebilmesidir. Ayrıca, ikna edici bilginin yararlılı̆̆ını değerlendirirken, ikna edici kişinin güvenilirliği, uzmanlığı, güvenilirliği ve saygınlığı gibi faktörleri göz önünde bulundurmak önemlidir (Bandura, 1977; Gist ve Mitchell, 1992). Gerçeği yansıtmayan teşvikler, kişilerin ortaya koyacağı tüm çabalara rağmen yaşanan başarısızlık sonucunda, kişilerdeki öz yeterlik duygusunun hızlı bir şekilde azalmasına sebebiyet verebilmektedir (Arseven, 2016: 69). Üçüncü yöntem olan sosyal ikna, ilk iki yöntemle kıyaslandığında, daha az etkili bir yöntem olarak ifade edilmektedir (Bandura, 1982; Gist, 1987).

\subsection{Somatik/Duygusal Durum}

Kişilerin stres ve kaygı düzeyleri, öz yeterlik duygularının gelişimini olumlu veya olumsuz olarak etkileyebilmektedir. Bununla birlikte bireyler, kişisel yetenekleri değerlendirirken, genellikle kendi fizyolojik durumlarına dair algıları ile yetinmektedir. $\mathrm{Bu}$ duygusal uyarılmalar ve gerginlikler, zayıf performansa karşı zayıflık göstergesi olarak yorumlanabilmektedir. Örneğin, hissedilen kaygı başarısızlık olasılığını artıracak ve öz yeterlik beklentilerini azaltacak zayıflatıcı korku olarak görülebilmektedir (Gist, 1987; Stumpf vd., 1987; Wood ve Bandura, 1989). Psikolojik olarak rahat olan bireylerin, bir işte başarılı olması konusunda yüksek düzeyde öz yeterliğe sahip olması beklenmektedir (Arseven, 2016: 69). Kaygı düzeyi ve öz yeterlik beklentileri arasında negatif bir ilişki olduğuna yönelik ampirik çalışmalar da bulunmaktadır (Stumpf vd., 1987). Ayrıca genel fiziksel durum, kişilik faktörleri ve bireyin duygu durumu gibi faktörler, bir kişinin bir 
görevle yüz yüze geldiğinde yaşadığı uyarılmayı etkileyerek öz yeterliği etkileyebilmektedir (Gist ve Mitchell, 1992). Bununla birlikte, öz yeterlik beklentisinin fizyolojik belirtileri, otonom uyarılmanın ötesine uzanmaktadır. Örneğin, egzersiz ve atletik performanslar gibi güç ve dayanıklılık içeren faaliyetlerde algılanan yeterlik, yorgunluk ve ağrı gibi deneyimlerden etkilenmektedir (Maddux, 2000: 10).

\section{3. Öz Yeterlik ve Akademik Performans Arasındaki İlişkiye Yönelik Yapılan Araştırmalar}

Öz yeterlik uzun bir süre akademik performansin önemli bir belirleyicisi olarak görülmüştür. Bu alanda yapılan çalışmalar genellikle, karşılıklılık veya iki yönlü etkilerin karşılaştırmalı gücünü ele almadan yapılan tek yönlü tasarımlar ile sınırlı kalmıştır. Talsma vd. (2018) tarafindan yapılan sistematik derleme ve meta-analizde, hem akademik öz yeterliği hem de akademik performansı ölçen boylamsal çalışmalardan veri toplanmıştır. $\mathrm{Bu}$ yöntemde ilişkinin her iki yönü de eş zamanlı olarak değerlendirilmiştir. Yapılan çalışmada, performansın, sonrasında oluşan öz yeterlik üzerinde net bir olumlu etkisi bulunduğu ortaya konulmuştur. Ayrıca, bu etkinin, öz yeterliğin performans üzerindeki etkisinden önemli ölçüde daha büyük olduğu belirlenmiştir. Yapılan moderatör analizlerinin ise, yalnızca yetişkinler için geçerli olduğu ve çocuklar için ayrı bir çalışmanın yapılması gerektiği de ifade edilmiştir (Talsma vd., 2018).

Bala vd. (2017) tarafından lise öğrencilerinin öz yeterlikleri ile demografik değişkenleri arasındaki ilişkiyi belirlemek için yapılan çalışmada, Haryana'daki (Hindistan) dört bölgeden 500 öğrenciye anket uygulanmıştır. Yapılan araştırma sonucunda, özel okul ve devlet okulu öğrencileri, kentsel ve kırsal okul öğrencileri, fen bilimleri ve sanatsal alanlarda öğrenim gören öğrenciler ile cinsiyet arasında önemli farklılıklar tespit edilmiştir. Yaş değişkeni ile öz yeterlik arasında ise herhangi bir farklılık belirlenmemiştir. Çalışma sonuçları incelendiğinde, kentsel alanlarda bulunan özel okul öğrencilerinin, fen bilimlerinde öğrenim gören öğrencilerin ve erkek öğrencilerin öz yeterlik puanlarının, kırsal kesimdeki devlet okullarında öğrenim gören öğrencilerden, sanat alanında öğrenim gören öğrencilerden ve kız öğrencilerden daha yüksek olduğu belirlenmiştir.

Akademik öz yeterlik ve sorumluluk, üniversite öğrencilerinin akademik performansını öngören iki önemli bireysel özelliktir. Jung vd. (2017) tarafından yapılan çalışmada, akademik öz disiplin olarak akademideki öz düzenleme çabası tanımlanmış ve bilişsel, bilişsel olmayan yordayıcılar, kişilik özellikleri ve akademik sonuçlar arasındaki ilişkiler incelenmiştir. Yapılan çalışma sonucunda, öz disiplinin, akademik öz yeterlik ile akademik performans arasındaki ilişkiye aracılık ettiği belirlenmiştir. Bu sonuç, akademik performanstaki akademik öz disiplinlerin önemini de ortaya koymaktadır (Jung vd., 2017).

Tsai vd. (2017) tarafından yapılan çalışmada, öğrencilerin öğrenme motivasyonu, kampüs dışı staj etkinliği, kariyer kararı öz yeterliği ve kariyer hazırlıkları arasındaki ilişkiyi incelemek amaçlanmıştır. Bu amaç doğrultusunda, Tayvan'da 613 üniversite öğrencisine anket uygulanmıştır. Çalışma sonuçları, öğrencilerin öğrenme motivasyonunun, staj etkinliğini olumlu ve önemli ölçüde etkilediğini ve kariyer kararı öz yeterliğinin, staj etkinliği ve kariyer hazırlığı arasında tam bir aracılık etkisi gösterdiğini göstermektedir (Tsai vd., 2017).

Bui vd. (2017) tarafından konaklama ve turizm bölümlerinde öğrenim gören yerli ve yabancı lisans öğrencilerine yönelik, öz yeterliğin akademik performans üzerindeki etkilerini 
belirlemek için yapılan araştırmada, bir eğitim-öğretim döneminden sonra, öz yeterlikteki gelişimin sadece yüksek performans gösteren öğrenciler arasında gerçekleştiği ortaya konulmuştur. Yerli öğrencilerin performanslarını öngörmede öz yeterlik anlamlı bulunmuşken, yabancı öğrenciler arasında olumlu bir ilişki belirlenememiştir.

Kontrol Değer Teorisi (Control-Value Theory), başarı ile ilgili duyguları ve ilgili performans1 öngördüğü varsayılan değişkenler dizisini belirtmektedir. Benzer şekilde, Schwarzer'in Öz-Düzenleme Teorisi (Theory of Self-Regulation) $(1998,2001)$, öz yeterliğin Kontrol Değer Teorisi'nde bahsedilen dizilimdeki bütün bağları etkilediğini göstermektedir. Bu nedenle, Roick ve Ringeisen (2017) tarafından yapılan çalışmada, kaygı belirleyicilerinin yapısını doğrulamak için uzunlamasına bir tasarım kullanılmış, böylece öz yeterliğin zincirin her bir bağı ile ilişkili olup olmadığı araştırılmıştır. Toplamda 92 öğrenciye anket uygulanarak yapılan çalışmada, Kontrol Değer Teorisi ve Öz-Düzenleme Teorisi varsayımlarını birleştiren modelin, sözlü sınav bağlamında, öz yeterlik, değerlendirme, test kaygısı ve performans arasındaki ilişkiyi en iyi şekilde ortaya koyduğu sonucuna varılmıştır.

Honicke ve Broadbent (2016) yapmış oldukları çalışmada, akademik öz yeterlik ile üniversite öğrencilerinin akademik performansı arasındaki ilişkiyi ve bu ilişkiyi açıklayan bilişsel ve motivasyonel değişkenleri 12 yıllık bir araştırma ile ortaya koymaktadır. Üniversitelerdeki akademik öz yeterlik ve performansı inceleyen çalışmalar için Nisan 2015 'te özellikle psikolojik, eğitsel ve ilgili çevrimiçi veriler kullanılarak sistematik bir araştırma yapılmıştır. Çalışmada, ilgili süreler içerisinde yayınlanan 59 makale ayrı ayrı incelenmiştir. İncelenen makaleler sonucunda, akademik öz yeterlik ile akademik performans arasında kısmen bir ilişkinin olduğu tespit edilmiştir. İncelenen çalışmalarda; çaba sarf etme, derin işleme stratejileri (psikolojik temelli) ve hedef yönelimli stratejiler başta olmak üzere bazı aracı ve düzenleyici değişkenler de ortaya konulmuştur. İlgili süreler içerisinde yapılmış olan çalışmaların yetersiz kalışı göz önüne alındığında, akademik öz yeterlik-performans ve onu etkileyen motivasyonel ve bilişsel değişkenler arasındaki karmaşı etkiyi açıklamak ve nedensellik oluşturmak için yapılacak araştırmalara ihtiyaç duyulduğu belirtilmektedir (Honicke ve Broadbent, 2016).

Yeşilyurt, Ulaş ve Akan (2016) tarafindan yapılan çalışmada ise, öğretmen öz yeterliği, akademik öz yeterlik, bilgisayar öz yeterliği, öğretmenlerin ve öğretmen adaylarının bilgisayar destekli eğitimine yönelik tutumları incelenmiştir. Bu araştırmada, öğretmen öz yeterliğinin gizli değişkenleri ve bu gizli değişkenlerin birbirleri ile oranları, akademik öz yeterlik, bilgisayar öz yeterliği ve bilgisayar destekli eğitim uygulamalarına yönelik tutumlar arasındaki etki düzeylerini test etmek amaçlanmıştır. Yapılan araştırmada, öğretmen öz yeterliği, akademik öz yeterlik ve bilgisayar öz yeterliğinin öğretmen adaylarının bilgisayar destekli eğitimi uygulama yönündeki tutumlarının önemli yordayıcıları olduğu sonucuna varılmıştır (Yeşilyurt vd., 2016).

Spor Bilimleri Fakültesi'ndeki lisans öğrencilerin akademik öz yeterlik düzeylerinin akademik başarıları üzerindeki etkisini ortaya koymak amacıyla yapılan araştırmada, akademik öz yeterlik arttıkça akademik başarının da arttığı ortaya konulmuştur (Sevilmiş ve Şirin, 2016). Ayrıca; Lane vd. (2004) tarafından yapılan araştırmada da akademik başarı ile öz yeterlik değişkeni arasında pozitif bir ilişki tespit edilmiştir. Diğer taraftan; Choi (2005), üniversite öğrencileri üzerinde yaptığı çalışmasında, öz yeterlik ve benlik kavramlarının 
birbirine yakınlaştıkça kavramlar arasındaki ilişki gücünün de aynı oranda artış gösterdiğini ortaya koymaktadır.

El-Hmoudova (2015) tarafından, Hradec Kralove Üniversitesi Turizm İşletmeciliği Bölümü'ndeki bir grup lisans öğrencisi üzerinde yapılan çalışmada ise, öğrencilerin öğrenme tercihleri ve öz yeterlik duyguları arasındaki ilişki incelenmiştir. Bu çalışmada, profesyonel İngilizce dilindeki araştırmalarda yer alan üniversite öğrencilerinin belirli öğrenme stili tercihlerinin, öğrenmeye yönelik öz yeterlikleriyle ilişkili olup olmadığı değerlendirilmiştir. Elde edilen sonuçlar, öğrencilerin akademik İngilizce dersi öz yeterlikleriyle tüm öğrenme tarzı tercihleri arasında pozitif yönde anlamlı bir ilişki olduğunu göstermektedir.

Akademik başarının sağlanmasında, motivasyonel yönelimlerin, bilişsel-üst bilişsel stratejilerin ve kaynak yönetiminin etkisinin incelendiği Komarraju ve Nadler (2013) tarafından yapılan çalışmada, 407 lisans öğrencisinden veri toplanmıştır. Yapılan analizler sonucunda, düşük öz yeterliğe sahip öğrencilerin, zekânın doğuştan geldiğine ve değişmez olduğuna inandığı belirlenmiştir. Bunun yanında yüksek öz yeterliğe sahip öğrencilerin de, iyi notlar içeren ve diğerlerinden daha iyi performans gösteren hedefleri kovaladıkları ve yeni bilgi elde etme hedefinde oldukları ortaya konulmuştur. Genel olarak yüksek öz yeterliğe sahip öğrencilerin, düşünüp hareket ettikleri, öz düzenleme yaptıkları ve zorluklar karşısında ısrarcı oldukları için akademik başarı elde ettikleri belirlenmiştir (Komarraju ve Nadler, 2013).

Capri vd. (2012) tarafından yapılan çalışmada ise, üniversite öğrencilerinin genel öz yeterlik inançları, yaşam doyumu ve tükenmişlik düzeyleri arasındaki ilişkiler incelenmiştir. 354 üniversite öğrencisine yönelik yapılan çalışma sonucunda, genel öz yeterlik inançları ile yaşam doyumu arasındaki ilişkilerden elde edilen pozitif anlamlı bulgular, alanyazındaki diğer araştırma sonuçlarıyla (Dahlke, 1992; Coffman ve Gilligan, 2002; Tong ve Song, 2004; Charrow, 2006) tutarlı bulunmuştur (Capri vd., 2012).

Yılmaz vd. (2012) tarafından yapılan başka bir çalışmada ise, ilköğretim öğrencilerinin öz yeterlik düzeylerinin akademik başarı, cinsiyet ve yaş gibi bir kısım değişkenler bakımından farklılık gösterip göstermediği incelenmiştir. Toplamda 5062 öğrenciye ulaşılan çalışma sonucunda, kız öğrencilerin erkek öğrencilere kıyasla, büyükşehirde oturan öğrencilerin diğer tüm yerleşim birimlerinde oturan öğrencilere kıyasla daha yüksek öz yeterlik puanlarına sahip olduğu belirlenmiştir. Ayrıca öğrencilerin öz yeterlik düzeyleri ile akademik başarıları arasında da pozitif yönlü bir ilişki tespit edilmiştir.

Öz yeterliğin, girişimci amaçlar ve eylemler üzerindeki etkisini ortaya koyabilmek için Boyd ve Vozikis (1994) yapmış oldukları çalışmada, bireyin görevini yerine getirme kabiliyeti olarak tanımlanan bireysel öz yeterliğin, hem girişimci niyetlerin, hem de eylemlerin veya davranışların gelişimini etkilediğini ortaya koymuşlardır. Bununla birlikte, bilişsel psikoloji teorisinde ele alınan Bird's modeli olarak bilinen girişimci niyet modeli ile öz yeterlik birlikte incelenmiştir.

Schunk (1989) ise araştırmasında; girişimci özellikleri, öğrenme için öz yeterlik, görev katılım değişkenleri ve yeterlik belirtilerinden oluşan bir model geliştirmiştir. Öğrencilerin öğrenme için öz yeterlik duygusu, ne kadar iyi öğrendiklerini gösteren işaretler ile görevleri üzerindeki çalışmalarından etkilenmektedir. Çalışmada, sosyal ve öğretici değiş̧kenlerin öz yeterlik ve başarı davranışları üzerindeki etkileri araştırılmıştır. Çalışma sonuçları, öz yeterliğin öğrencilerin motivasyon ve öğrenmesine yönelik yordamda bulunduğu sonucunu desteklemektedir. 
Gecas (1989) tarafından yapılan çalışmada, bireysel işlevsellik ve sosyal değişim için öz yeterlikle ilgili kavramlar incelenmiştir. Öz yeterliğin gelişimine ilişkin alanyazın taramas1 yapılarak, sosyal yap1 ve grup süreçlerinin bu gelişmeyi nasıl etkilediği araştırılmıştır. Yaşam içerisindeki öz yeterlik değişimleri ele alınarak sonuçlar değerlendirilmiştir. Çalışmada, sosyal psikoloji alanyazını üzerinde durulurken, sosyoloji, psikoloji ve politik bilimlerden de faydalanılmıştır. Yüksek öz yeterliğe sahip olmanın önemine değinilen çalışmada, yüksek öz yeterliğin daha iyi fiziksel ve psikolojik sağlık, yaratıcılık, bilişsel esneklik, daha iyi problem çözme ve problemlerle baş edebilme becerileri, daha iyi benlik saygısı gibi toplum içinde bile bireylere olumlu ya da faydalı sonuçlar oluşturabileceği belirlenmiştir.

Farklı tedavi biçimleriyle elde edilen psikolojik değişimleri açıklamak ve tahmin etmek için bütünleştirici kuramsal bir çerçevenin sunulduğu çalışmada ise Bandura (1977), geliştirdiği teorinin, formları ne olursa olsun psikolojik prosedürlerin, öz yeterliğin gücünü ve düzeyini değiştirdiğini ifade etmektedir. Deneyimsel kaynakların gücü oranında ise, algılanan öz yeterlikte değişiklikler meydana gelmektedir. Çalışma bulguları, algılanan öz yeterlik ve davranışsal eğilimler arasındaki ilişkiyi desteklemektedir (Bandura, 1977).

Öz yeterlik ile akademik performans arasındaki ilişkiye yönelik yapılan ve yukarıda ifade edilen bazı çalışmalar (Schunk, 1989; Lane vd., 2004; Yılmaz vd., 2012; Komarraju ve Nadler, 2013; El-Hmoudova, 2015; Honicke ve Broadbent, 2016; Yeşilyurt vd., 2016; Sevilmiş ve Şirin, 2016; Bui vd., 2017; Roick ve Ringeisen, 2017; Jung vd., 2017; Tsai vd., 2017; Talsma vd., 2018) göz önüne alındığında, öz yeterliğin akademik performans üzerinde pozitif yönlü bir ilişkiye sahip olduğu sonucu ortaya çıkmaktadır. Öğrencilerin öz yeterlik düzeylerinin yüksek olması onların akademik başarıları üzerinde olumlu, öz yeterlik düzeylerinin düşük olması ise akademik başarıları üzerinde olumsuz bir etki oluşturması beklenmektedir.

İlgili alanyazın incelendiğinde, farklı eğitim kademelerindeki öğrencilerin öz yeterlikleri ile akademik başarıları arasındaki ilişkiyi araştıran çok sayıda çalışmanın olduğu, turizm alanındaki öğrencilere yönelik ise sınırlı sayıda araştırmanın (Bui vd., 2017; ElHmoudova, 2015) yapıldığı görülmektedir. Ayrıca, özellikle yerli alanyazında turizm eğitimi almakta olan lisans öğrencilerinin öz yeterlikleri ile bireysel özellikleri ve akademik başarıları arasındaki ilişkinin araştırıldığı bir çalışmaya rastlanılmamış olması da, ilgili boşluğu doldurması ve alan yazına sağlayacağı katkı açısından bu araştırmanın önemi olarak ifade edilebilir.

\section{Yöntem}

\subsection{Araştırmanın Amacı}

$\mathrm{Bu}$ araştırmanın amacı, turizm eğitimi almakta olan lisans öğrencilerinin öz yeterlik algılarının bireysel özelliklerine ve akademik başarı düzeylerine göre farklılık gösterip göstermediğini tespit etmektir. $\mathrm{Bu}$ amaçla oluşturulan araştırma modeli ve araştırma hipotezleri şu şekildedir: 


\section{Şekil 2. Araştırma Modeli}

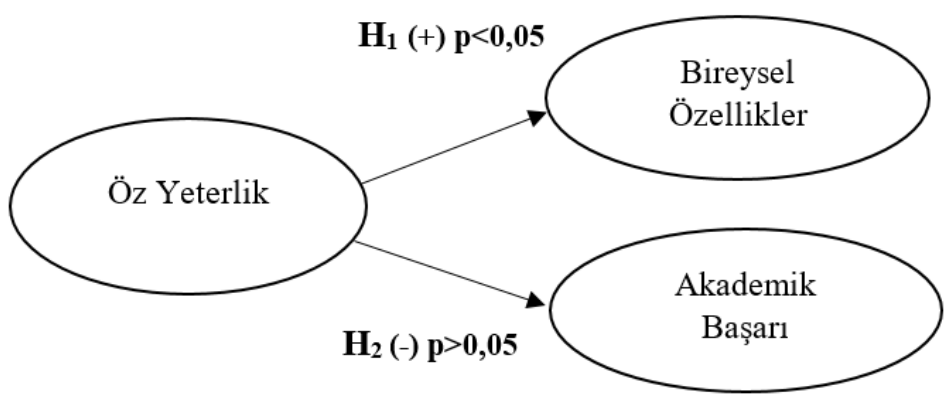

$\mathbf{H}_{\mathbf{1}}$ : Turizm eğitimi almakta olan lisans öğrencilerinin öz yeterlikleri, bireysel özelliklerine göre anlamlı bir farklıl1k gösterir.

$\mathbf{H}_{\mathbf{2}}$ : Turizm eğitimi almakta olan lisans öğrencilerinin öz yeterlikleri, akademik başarı düzeylerine göre anlamlı bir farklılık gösterir.

\subsection{Evren ve Örneklem}

Araştırmanın ideal/hedef evrenini lisans düzeyinde turizm eğitimi almakta olan öğrenciler oluşturmaktadır. Uygulanabilir/gerçekçi evren ise, Gazi Üniversitesi Turizm Fakültesi'ndeki yaklaşık 1.900 öğrenciden oluşmaktadır. Araştırma evreninin geniş olması nedeniyle, lisans düzeyinde öğrenim gören tüm turizm öğrencilerine ulaşmak mümkün değildir. Bu yüzden, maliyet ve zaman gerekçelerine dayanılarak bir örneklem belirlenmesi gerekmektedir. Araştırma örnekleminin belirlenmesinde ise Yamane (2001) örneklem formülü kullanılmıştır (Yamane, 2001: 116). Bu formüle göre araştırma evreni 1.900 olarak kabul edildiğinde, araştırma örneklemi de \% 95 güven seviyesinde en az 384 kişi olarak hesaplanmaktadır. Basit tesadüfi örnekleme yöntemine göre seçilen örneklem grubundan araştırmaya katılmayı kabul eden öğrencilere soru formları dağıtılarak veriler yüz yüze toplanmıştır. Araştırma 2017-18 ve 2018-19 eğitim öğretim dönemlerinde yapılmıştır. Eksiksiz doldurulan 514 anket formu değerlendirmeye alınarak veri analizine tabi tutulmuştur.

\subsection{Verilerin Toplanması}

Araştırmada veri toplama aracı olarak anket formu kullanılmıştır. Anket formunun birinci bölümü, katılımcıların bireysel ve akademik özelliklerini belirlemeye yönelik açık ve kapalı uçlu önermelerden oluşmaktadır. İkinci bölümü ise, öz yeterlik düzeylerini ölçmeye yönelik Sherer ve diğerleri (1982) tarafından geliştirilen ve Türkçe geçerlilik ve güvenilirlik çalışması Yıldırım ve İlhan (2010) tarafindan yapılan Genel Öz Yeterlik Ölçeğinden oluşmaktadır. 17 maddeden oluşan Genel Öz Yeterlik Ölçeği, 5'li Likert olarak derecelendirilmiştir. Ölçekten alınan puanlar 17 ile 85 arasında değişmekte olup, puanın yükselmesi katılımcıların öz yeterlik inancının arttığını göstermektedir. Öz yeterlik ölçeği; başlama ( 9 madde), yılmama ( 5 madde) ve sürdürme çabası ve ısrar (3 madde) olmak üzere üç boyuttan oluşmaktadır. Araştırmada kullanılan genel öz yeterlik ölçeğinin güvenilirliğini belirlemek amacıyla Cronbach Alpha güvenirlik katsayısı hesaplanmış ve yüksek güven aralığında çıkmıştır $(\alpha=0,86)$. Elde edilen sonuçlar, ölçeğin güvenilir olduğunu ortaya koymaktadır. 


\subsection{Verilerin Analizi}

Anket formundan elde edilen verilerin analizi için SPSS istatistik veri programından yararlanılmıştır. Verilerin yüzde ve frekans dağglımı ile standart sapma ve aritmetik ortalama değerleri hesaplanarak elde edilen bulgular tablo haline getirilmiştir. Araştırmaya katılanların bireysel özellikleri ve akademik başarı düzeyleri ile genel öz yeterlik durumları arasında farklılık olup olmadığını belirleyebilmek için Bağımsız Örneklemler için $t$-testi ve ANOVA testi yapılmıştır.

Verilerin normal dağılım gösterip göstermediğini test edebilmek amaciyla Kolmogorov-Smirnov testi uygulanmış $(\mathrm{p}=0,182 ; \mathrm{p}>0,05)$ ve $\mathrm{Q}-\mathrm{Q}$ grafiği incelenmiştir. Özellikle 100 ve daha geniş örneklemlerdeki büyük gruplarda, grafik yöntemi örneklemden görece bağımsız olduğu için daha sık kullanılmaktadır (Çokluk vd., 2010: 15). Bu grafikte gözlenen değerler köşegenler odağındaki doğrunun yakınında toplandıkları için normalden sapma olmamış ve değişkenler normal bir dağılım göstermiş̧ir. Bu çalışmadaki verilerin ve değişkenlerin normal dağılıma sahip olması, verilerin nicel özellikte olması, örneklemi oluşturan deneklerin birbirinden bağımsız olması, örneklem büyüklüğünün 30'dan büyük ve varyansların homojen olmasından dolayı parametrik testler kullanılmıştır (Altunışık vd., 2010: 180; Ural ve Kilıç, 2013: 83).

\section{Bulgular}

$\mathrm{Bu}$ bölümde araştırmaya katılan öğrencilerin bireysel özellikleri, akademik başarı düzeyleri ve öz yeterlik ölçeğine ilişkin tanımlayıcı analiz bulguları ile araştırma hipotezlerini test etmeye yönelik analiz sonuçlarına yer verilmiştir:

Tablo 1'de araştırmaya katılan öğrencilerin bireysel özelliklerinin betimlenmesine ilişkin frekans ve yüzde analizi sonuçları yer almaktadır. Tablodaki verilere göre katılımcıların çoğunluğu; kadın (\% 61,1), 21-23 yaş aralığındaki $(\% 63,6)$ ve Seyahat İşletmeciliği ve Turizm Rehberliği Bölümü'nde okuyan öğrencilerden (\% 39,9$)$ oluşmaktadır. Öğrencilerin mezun oldukları liseye göre dağ 11 lıları incelendiğinde, Turizm Meslek Lisesi ve Anadolu Lisesi'nden mezun olanların oranlarının aynı olduğu $(\% 28,4)$ görülmektedir. Öğrencilerin çok büyük bir kısmı (\% 71,2) üniversiteden önce uzun süreli yaşadıkları yerleşim yerini il olarak belirtmişlerdir. Konakladıkları yer açısından incelendiğinde ise, çoğunluğu $(\% \quad 47,7)$ ailesi ile birlikte kalanların oluşturduğu görülmektedir. Öğrencilerin büyük bir kısmının (\% 71) fakülte veya üniversite genelinde herhangi bir öğrenci topluluğuna üye olmadıkları, bununla birlikte çoğunluğun $(\% 73,7)$ okudukları bölüme isteyerek geldikleri görülmektedir. 
Tablo 1. Katılımcıların bireysel özelliklerine ilişkin frekans ve yüzde analizi sonuçları

\begin{tabular}{|c|c|c|c|c|c|}
\hline Grup & $\bar{f}$ & $\%$ & Grup & $f$ & $\%$ \\
\hline Cinsiyet & & & Bölüm & & \\
\hline & & & Sey. İşl. ve Tur. Reh. & 205 & 39,9 \\
\hline Kadın & 314 & 61,1 & Turizm İşletmeciliği & 168 & 32,7 \\
\hline \multirow[t]{2}{*}{ Erkek } & 200 & 38,9 & Gast. ve Mutfak San. & 74 & 13,0 \\
\hline & & & Rekreasyon Yön. & 67 & 14,4 \\
\hline Toplam & 514 & 100 & Toplam & 514 & 100 \\
\hline Yaş & & & $\begin{array}{l}\text { Üniversiteden önce uzun } \\
\text { süreli yaşantlan yer }\end{array}$ & & \\
\hline $18-20$ & 138 & 26,8 & Il & 366 & 71,2 \\
\hline $21-23$ & 327 & 63,6 & İlçe & 120 & 23,3 \\
\hline $24-26$ & 38 & 7,4 & Köy & 14 & 2,7 \\
\hline 27 ve üzeri & 11 & 2,1 & Kasaba & 8 & 1,6 \\
\hline Toplam & 514 & 100 & Toplam & 508 & 98,8 \\
\hline Mezun Olunan Lise & & & Konaklama Yeri & & \\
\hline Turizm Meslek Lisesi & 146 & 28,4 & Aile ile & 245 & 47,7 \\
\hline Anadolu Lisesi & 146 & 28,4 & Devlet yurdu & 124 & 24,1 \\
\hline Genel Lise & 108 & 21,0 & Öğrenci evi & 96 & 18,7 \\
\hline Kız Meslek Lisesi & 68 & 13,2 & Özel yurt & 29 & 5,6 \\
\hline Ticaret Meslek Lisesi & 17 & 3,3 & Akraba yanında & 10 & 1,9 \\
\hline Diğer & 29 & 5,6 & Diğer & 9 & 1,8 \\
\hline Toplam & 514 & 100 & Toplam & 513 & 99,8 \\
\hline $\begin{array}{l}\text { Üniversite veya fakültede herhangi bir } \\
\text { öğrenci topluluğuna üye misiniz? }\end{array}$ & & & $\begin{array}{l}\text { Okuduğunuz bölüme } \\
\text { isteyerek mi geldiniz? }\end{array}$ & & \\
\hline Evet & 143 & 27,8 & Evet & 379 & 73,7 \\
\hline Hayır & 365 & 71,0 & Hayır & 128 & 24,9 \\
\hline Toplam & 508 & 98,8 & Toplam & 507 & 98,6 \\
\hline
\end{tabular}

Tablo 2'de ise katılımcıların akademik başarı düzeylerine ilişkin frekans ve yüzde analizi bulguları yer almaktadır. Öğrencilerin akademik başarı durumları, araştırma yapıldığı dönem itibariyle aritmetik genel not ortalaması dikkate alınarak belirlenmiştir. Buna göre aritmetik genel not ortalaması (AGNO) 2,00'ın altında olanlar "çok düşük"; 2,00-2,49 arasında olanlar "düşük"; 2,50-2,99 arasında olanlar "orta"; 3,00-3,49 arasında olanlar "yüksek" ve 3,50-4,00 arasında olanlar ise "çok yüksek" olarak sınıflandırılmıştır.

Tablo 2. Katılımcıların akademik başarı düzeylerine ilişkin frekans ve yüzde dağılımı

\begin{tabular}{|lcc|}
\hline Akademik Başarı Düzeyi & $\boldsymbol{f}$ & $\boldsymbol{\%}$ \\
\hline Çok düşük & 36 & 7,0 \\
\hline Düşük & 152 & 29,6 \\
\hline Orta & 200 & 38,9 \\
\hline Yüksek & 97 & 18,9 \\
\hline Çok yüksek & 24 & 4,7 \\
\hline Toplam & $\mathbf{5 0 9}$ & $\mathbf{9 9 , 0}$ \\
\hline
\end{tabular}

Öğrencilerin akademik başarı durumları dikkate alındığında çoğunluğu "orta başarı düzeyindeki” (\% 38,9) öğrencilerin oluşturduğu görülmektedir. Tablo 3’te ise, öz yeterlik ölçeğindeki maddelere verilen cevaplara ilişkin frekans ve yüzde analizi sonuçları yer almaktadır: 
Tablo 3. Araştırmaya katılanların genel öz yeterlik algılarına yönelik frekans, yüzde, ortalama ve standart sapma değerleri (*ters kodlu önermelerdir)

\begin{tabular}{|c|c|c|c|c|c|c|c|c|}
\hline İfade & $\begin{array}{l}\mathbf{f} \\
\%\end{array}$ & $\begin{array}{c}1 \\
1 \\
\text { (Kesinlikle } \\
\text { Hayır) }\end{array}$ & 2 & 3 & 4 & $\begin{array}{c}5 \\
\text { (Kesinlikl } \\
\text { e Evet) }\end{array}$ & $X$ & S.s. \\
\hline \multirow{2}{*}{$\begin{array}{l}\text { 1) Planlar yaparken, onları hayata } \\
\text { geçirebileceğimden eminimdir. }\end{array}$} & f & 8 & 40 & 162 & 191 & 113 & \multirow{2}{*}{$\begin{array}{c}3,7 \\
0\end{array}$} & \multirow{2}{*}{0,94} \\
\hline & $\%$ & 1,6 & 7,8 & 31,5 & 37,2 & 22 & & \\
\hline \multirow{2}{*}{$\begin{array}{l}\text { 2) Sorunlarımdan birisi, bir işe zamanında } \\
\text { başlayamamamdır.* }\end{array}$} & f & 113 & 149 & 103 & 105 & 44 & \multirow{2}{*}{$\begin{array}{c}2,6 \\
5\end{array}$} & \multirow{2}{*}{1,26} \\
\hline & $\%$ & 22,0 & 29,0 & 20,0 & 20,4 & 8,6 & & \\
\hline \multirow{2}{*}{$\begin{array}{l}\text { 3) Eğer bir işi ilk denemede yapamazsam } \\
\text { başarana kadar uğraşırım. }\end{array}$} & f & 14 & 36 & 131 & 172 & 161 & \multirow{2}{*}{$\begin{array}{c}3,8 \\
4\end{array}$} & \multirow{2}{*}{1,03} \\
\hline & $\%$ & 2,7 & 7,0 & 25,5 & 33,5 & 31,3 & & \\
\hline \multirow{2}{*}{$\begin{array}{l}\text { 4) Belirlediğim önemli hedeflere ulaşmada, } \\
\text { pek başarıll olamam.* }\end{array}$} & f & 162 & 201 & 91 & 47 & 12 & \multirow{2}{*}{$\begin{array}{c}2,1 \\
2\end{array}$} & \multirow{2}{*}{1,02} \\
\hline & $\%$ & 31,5 & 39,1 & 17,7 & 9,1 & 2,3 & & \\
\hline \multirow{2}{*}{ 5) Her şeyi yarım bırakırım.* } & f & 245 & 161 & 74 & 20 & 13 & \multirow{2}{*}{$\begin{array}{c}1,8 \\
2\end{array}$} & \multirow{2}{*}{0,98} \\
\hline & $\%$ & 47,7 & 31,3 & 14,4 & 3,9 & 2,5 & & \\
\hline \multirow{2}{*}{$\begin{array}{l}\text { 6) Zorluklarla yüz yüze gelmekten } \\
\text { kaçınırım.* }\end{array}$} & f & 230 & 137 & 93 & 37 & 16 & \multirow{2}{*}{$\begin{array}{c}1,9 \\
7\end{array}$} & \multirow{2}{*}{1,09} \\
\hline & $\%$ & 44,7 & 26,7 & 18,1 & 7,2 & 3,1 & & \\
\hline \multirow{2}{*}{$\begin{array}{l}\text { 7) Eğer bir iş çok karmaşık görünüyorsa } \\
\text { onu denemeye bile girişmem.* }\end{array}$} & f & 210 & 145 & 105 & 30 & 20 & \multirow{2}{*}{$\begin{array}{c}2,0 \\
3\end{array}$} & \multirow{2}{*}{1,09} \\
\hline & $\%$ & 40,9 & 28,2 & 20,4 & 5,8 & 3,9 & & \\
\hline \multirow{2}{*}{$\begin{array}{l}\text { 8) Hoşuma gitmeyen bir şey yapmak } \\
\text { zorunda kaldığımda onu bitirinceye kadar } \\
\text { kendimi zorlarım. }\end{array}$} & $\mathbf{f}$ & 48 & 84 & 138 & 136 & 108 & \multirow{2}{*}{$\begin{array}{c}3,3 \\
3\end{array}$} & \multirow[b]{2}{*}{1,23} \\
\hline & $\%$ & 9,3 & 16,3 & 26,8 & 26,5 & 21,0 & & \\
\hline \multirow{2}{*}{$\begin{array}{l}\text { 9) Bir şey yapmaya karar verdiğimde } \\
\text { hemen işe girişirim. }\end{array}$} & f & 12 & 55 & 157 & 149 & 139 & \multirow{2}{*}{$\begin{array}{c}3,6 \\
8\end{array}$} & \multirow{2}{*}{1,05} \\
\hline & $\%$ & 2,3 & 10,7 & 30,5 & 29,0 & 27,0 & & \\
\hline 10) Yeni bir şey denerken başlangıçta & f & 184 & 170 & 106 & 38 & 15 & 2,0 & \\
\hline başarılı olamazsam çabucak vazgeçerim.* & $\%$ & 35,8 & 33,1 & 20,6 & 7,4 & 2,9 & 8 & 1,05 \\
\hline 11) Beklenmedik sorunlarla karşılaştığımda & f & 132 & 188 & 137 & 43 & 11 & 2,2 & \\
\hline kolayca onların üstesinden gelemem.* & $\%$ & 25,7 & 36,6 & 26,7 & 8,4 & 2,1 & 4 & 1,00 \\
\hline 12) Bana zor görünen yeni şeyleri & f & 234 & 151 & 95 & 24 & 10 & 1,8 & 000 \\
\hline öğrenmeye çalışmaktan kaçınırım. * & $\%$ & 45,5 & 29,4 & 18,5 & 4,7 & 1,9 & 8 & 0,99 \\
\hline & f & 48 & 73 & 188 & 106 & 96 & 3,2 & \\
\hline 13) Başarısızlık benım azmımı arttırır. & $\%$ & 9,3 & 14,2 & 36,6 & 20,6 & 18,7 & 5 & 1,19 \\
\hline 14) Yeteneklerime her zaman çok & $\mathbf{f}$ & 143 & 143 & 153 & 57 & 18 & 2,3 & \\
\hline güvenmem.* & $\%$ & 27,8 & 27,8 & 29,8 & 11,1 & 3,5 & 5 & 1,10 \\
\hline & f & 9 & 31 & 99 & 168 & 206 & 4,0 & \\
\hline 15) Kendine guvenen birıyım. & $\%$ & 1,8 & 6,0 & 19,3 & 32,7 & 40,1 & 4 & 0,99 \\
\hline & $\mathbf{f}$ & 258 & 155 & 75 & 18 & 8 & 1,7 & \\
\hline 16) Kolayca pes ederim.* ${ }^{*}$ & $\%$ & 50,2 & 30,2 & 14,6 & 3,5 & 1,6 & 6 & 0,93 \\
\hline 17) Hayatta karşıma çıkacak sorunların & f & 233 & 145 & 82 & 36 & 18 & 1,9 & 100 \\
\hline çoğuyla baş edebileceğimi sanmıyorum.* & $\%$ & 45,3 & 28,2 & 16,0 & 7,0 & 3,5 & 5 & 1,09 \\
\hline
\end{tabular}

Tablo 3'te araştırmaya katılan öğrencilerin öz yeterlik ölçeğine verdikleri cevaplara ilişkin yüzde ve frekans ile aritmetik ortalama ve standart sapma değerleri yer almaktadır. En yüksek ortalamaya sahip önerme "kendine güvenen biriyim" ( $\bar{X}=4,04)$ olmakla birlikte, en düşük önerme ise "kolayca pes ederim" $(\bar{X}=1,76)$ olmuştur. Tablo 4'te araştırmanın hipotezlerinden birincisinin $\left(\mathrm{H}_{1}\right)$ test edilmesine ilişkin bulgular yer almaktadır: 
Kızanlıklı ve Silik / Turizm Eğitimi Alan Lisans Öğrencilerinin Öz Yeterliklerinin Akademik Başarı ve Bireysel Özellikler Açısından İncelenmesi / Examination of the Self-Efficacy of Undergraduate Students in Tourism Education in terms of Academic Achievement and Individual Characteristics

Tablo 4. Araştırmaya katılanların bireysel özellikleri ile genel öz yeterlik algıları arasındaki farklılığa ilişkin $\mathrm{t}$ testi ve anova testi sonuçları

\begin{tabular}{|c|c|c|c|c|c|c|}
\hline \multicolumn{2}{|c|}{ Bireysel Özellikler } & $\mathbf{n}$ & $\sum$ & S.S. & $F / t$ & $\mathbf{p}$ \\
\hline \multirow{2}{*}{ Cinsiyet } & Kadın & 314 & 64,9 & 9,8 & \multirow{2}{*}{0,213} & \multirow{2}{*}{0,831} \\
\hline & Erkek & 200 & 64,7 & 10,2 & & \\
\hline \multirow{4}{*}{ Yaş } & $18-20$ & 138 & 64,4 & 9,3 & \multirow{4}{*}{1,541} & \multirow{4}{*}{0,203} \\
\hline & $21-23$ & 327 & 65,1 & 10,1 & & \\
\hline & $24-26$ & 38 & 62,8 & 10,5 & & \\
\hline & 27 ve üzeri & 11 & 69,7 & 9,4 & & \\
\hline \multirow{6}{*}{$\begin{array}{c}\text { Mezun olunan } \\
\text { lise }\end{array}$} & Turizm Meslek Lisesi $^{a}$ & 146 & 65,5 & 10,1 & \multirow{6}{*}{2,847} & \multirow{6}{*}{$\begin{array}{l}0,015 * \\
(\mathbf{a}, \mathbf{c}-b)\end{array}$} \\
\hline & Anadolu Lisesi & 146 & 65,0 & 9,8 & & \\
\hline & Genel Lise $^{b}$ & 108 & 61,8 & 10,1 & & \\
\hline & ${ }_{\text {Klz Meslek Lisesi }}{ }^{c}$ & 68 & 66,3 & 8,9 & & \\
\hline & Ticaret Meslek Lisesi & 17 & 65,5 & 8,8 & & \\
\hline & Diğer & 29 & 67,3 & 9,7 & & \\
\hline \multirow{4}{*}{$\begin{array}{c}\text { Üniversiteden } \\
\text { önce uzun } \\
\text { süreli } \\
\text { yaşanılan yer }\end{array}$} & $\dot{I l}$ & 366 & 64,9 & 10,3 & \multirow{4}{*}{1,173} & \multirow{4}{*}{0,319} \\
\hline & Illçe & 120 & 65,1 & 9,1 & & \\
\hline & $K \ddot{y} y$ & 14 & 60,7 & 8,4 & & \\
\hline & Kasaba & 8 & 68,3 & 6,0 & & \\
\hline \multirow{6}{*}{$\begin{array}{c}\text { Konaklama } \\
\text { yeri }\end{array}$} & Aile ile & 245 & 65,4 & 10,0 & \multirow{6}{*}{1,804} & \multirow{6}{*}{0,110} \\
\hline & Devlet yurdu & 124 & 64,0 & 9,4 & & \\
\hline & Ögrenci evi & 96 & 65,0 & 10,4 & & \\
\hline & Özel yurt & 29 & 64,2 & 8,1 & & \\
\hline & Akraba yanında & 10 & 57,8 & 11,4 & & \\
\hline & Diğer & 9 & 69,7 & 12,8 & & \\
\hline \multirow{4}{*}{ Bölüm } & Seyahat İsl.ve Tur. Reh. & 205 & 64,3 & 10,0 & \multirow{4}{*}{1,360} & \multirow{4}{*}{0,254} \\
\hline & Turizm Işsl. & 168 & 66,0 & 10,0 & & \\
\hline & Gast. Mutf. San. & 67 & 63,6 & 10,1 & & \\
\hline & Rek. Ÿ̈n. & 74 & 64,7 & 9,3 & & \\
\hline \multirow{2}{*}{ Bölüm tercihi } & Isteyerek & 379 & 65,9 & 9,7 & \multirow{2}{*}{4,036} & \multirow{2}{*}{$\mathbf{0 , 0 0 0 *}$} \\
\hline & Istemeyerek & 128 & 61,8 & 10,1 & & \\
\hline \multirow{2}{*}{$\begin{array}{c}\text { Öğrenci } \\
\text { topluluğuna } \\
\text { üyelik }\end{array}$} & Evet & 143 & 66,4 & 9,6 & \multirow{2}{*}{2,115} & \multirow{2}{*}{$\mathbf{0 , 0 3 5 *}$} \\
\hline & Hayır & 365 & 64,4 & 9,9 & & \\
\hline
\end{tabular}

$$
* \mathrm{p}<0.05
$$

Tablo 4'teki analiz bulguları değerlendirildiğinde, katılımcıların öz yeterlik düzeylerinin mezun olunan lise $(\mathrm{p}=0,015)$, bölüme yerleşme isteği $(\mathrm{p}=0,000)$ ve herhangi bir öğrenci topluluğuna üyelik durumuna göre $(\mathrm{p}=0,035)$ anlamlı bir farkl11ık gösterdiği tespit edilmiştir. Farklılığın kaynağını belirlemeye yönelik yapılan Tukey testi sonuçlarına göre ise, aralarında farklılık tespit edilen Turizm Meslek Lisesi ve Kız Meslek Lisesi mezunlarının öz yeterlik toplam puanlarının Genel Liseden mezun olanlara kıyasla daha yüksek olduğu görülmektedir. Diğer taraftan okudukları bölüme isteyerek gelen öğrencilerin istemeden yerleşenlere ve herhangi bir öğrenci topluluğuna üye olanların, olmayanlara kıyasla öz yeterlik toplam puanlarının daha yüksek olduğu ortaya çıkmıştır. Elde edilen bulgular doğrultusunda kısmen de olsa ilgili araştırma hipotezinin $\left(\mathbf{H}_{\mathbf{1}}\right.$ : Turizm eğitimi almakta olan lisans öğrencilerinin öz yeterlikleri, bireysel özelliklerine göre anlamlı bir farkl1lık gösterir.) kabul edildiği söylenebilir.

Tablo 5 'te ise araştırmanın ikinci hipotezinin $\left(\mathrm{H}_{2}\right)$ test edilmesine ilişkin bulgular yer almaktadır: 
Tablo 5. Araştırmaya katılanların akademik başarı düzeyleri ile genel öz yeterlik algıları arasındaki farklılığa ilişkin anova testi sonuçları

\begin{tabular}{|c|c|c|c|c|c|}
\hline Akademik Başarı Düzeyi & $\mathbf{N}$ & $\bar{\Sigma}$ & S.S. & $\mathbf{F}$ & $\mathbf{p}$ \\
\hline Çok düşük & 36 & 63,80 & 12,6 & \multirow{5}{*}{1,441} & \multirow{5}{*}{0,219} \\
\hline Düşük & 152 & 63,75 & 10,6 & & \\
\hline Orta & 200 & 64,93 & 9,0 & & \\
\hline Yüksek & 97 & 65,91 & 9,0 & & \\
\hline Çok yüksek & 24 & 68,00 & 11,3 & & \\
\hline
\end{tabular}

Elde edilen bulgulara göre öğrencilerin genel öz yeterlik algıları ile akademik başarı düzeyleri arasında anlamlı bir farklılık tespit edilememiştir ( $>0.05)$. $\mathrm{Bu}$ nedenle $\mathrm{H}_{2}$ 'ye ilişskin null hipotez reddedilememiştir $\left(\mathbf{H}_{\mathbf{0}}\right.$ : Turizm eğitimi almakta olan lisans öğrencilerinin öz yeterlikleri, akademik başarı düzeylerine göre anlamlı bir farklılık göstermez). Diğer taraftan istatistiksel olarak anlamlı bir farklılık göstermemekle birlikte, öğrencilerin öz yeterlik toplam puanları dikkate alındığında; öğrencilerin akademik başarı düzeyleri yükseldikçe, genel öz yeterlik puanlarının da arttığı görülmektedir.

\section{Sonuç Ve Öneriler}

Araştırmaya katılan öğrencilerin öz yeterlik düzeylerinin bireysel özellikler arasından mezun olunan lise türü, bölüme yerleşme tercihi ve öğrenci topluluğuna üye olma durumuna göre farklılık gösterdiği tespit edilmiştir $(p<0,05)$. Buna göre turizm meslek lisesi ve kız meslek lisesi mezunu olan öğrencilerin genel liseden mezun olanlara kıyasla; herhangi bir öğrenci topluluğuna üye olanların ve okudukları bölüme isteyerek gelen öğrencilerin ise diğer öğrencilere kıyasla öz yeterlik düzeylerinin daha yüksek olduğu ortaya çıkmıştır. Elde edilen sonuçlar, alanyazındaki bireysel özellik ve öz yeterlik arasındaki ilişkiyi ölçen bazı çalışma bulgularıyla (Bala vd., 2017; Yılmaz vd., 2012) örtüşmektedir.

Diğer taraftan alanyazındaki benzer araştırmaların (Schunk, 1989; Carini vd., 2006; Komarraju ve Nadler, 2013; Jung vd., 2017; Bui vd., 2017) aksine bu çalışmada, öğrencilerin genel öz yeterlik durumlarının akademik başarı düzeylerine göre anlamlı bir farklılık göstermediği tespit edilmiştir. İstatistiksel olarak anlamlı bir farklılık çıkmamakla birlikte, ölçekteki ifadelere verilen toplam değerler dikkate alındığında öğrencilerin akademik başarı düzeyleri yükseldikçe, genel öz yeterlik düzeylerinin de arttığı tespit edilmiştir. Ayrıca, üniversitelerdeki akademik öz yeterlik ve performansı inceleyen çalışmalar için Nisan 2015 'te özellikle psikolojik, eğitsel ve ilgili çevrimiçi veriler kullanılarak Honicke ve Broadbent (2016) tarafından sistematik bir araştırma yapılmıştır. Çalışmada, ilgili süreler içerisinde yayınlanan 59 makale ayrı ayrı incelenmiştir. İncelenen makaleler sonucunda, akademik öz yeterlik ile akademik performans arasında kısmen bir ilişkinin olduğu tespit edilmiştir. İncelenen çalışmalarda; çaba sarf etme, derin işleme stratejileri (psikolojik temelli) ve hedef yönelimli stratejiler başta olmak üzere bazı aracı ve düzenleyici değişkenler de ortaya konulmuştur. İlgili süreler içerisinde yapılmış olan çalışmaların yetersiz kalışı göz önüne alındığında, akademik öz yeterlik-performans ve onu etkileyen motivasyonel ve bilişsel değiş̧enler arasındaki karmaşık etkiyi açıklamak ve nedensellik oluşturmak için yapılacak araştırmalara ihtiyaç duyulduğu belirtilmektedir. 
$\mathrm{Bu}$ araştırmadan elde edilen bulgular doğrultusunda, bundan sonra yapılacak araştırmalarda; turizm eğitimi alan lisans öğrencilerinin öz yeterlik düzeyleri ile akademik başarı durumları arasındaki ilişkinin farklı değişkenlerle birlikte araştırılması ve bu araştırmada ele alınmayan diğer bireysel özellikler ile farklı ölçeklerin bağımsız değişkenler olarak araştırma modeline dâhil edilmesi önerilebilir.

\section{Kaynakça}

Ajzen, I. (1987). Attitudes, Traits and Actions; Dispositional Prediction of Behavior in Personality and Social Psychology. Advances in Experimental Social Psychology, San Diego: Academic Press.

Alivernini, F. and Lucidi, F. (2011). Relationship between social context, self-efficacy, motivation, academic achievement, and intention to drop out of high school: A longitudinal study. The Journal of Educational Research, 104, 241-252.

Altunışık, R., Recai, C., Serkan, B. ve Engin, Y. (2010). Sosyal Bilimlerde Araştırma Yöntemleri: SPSS Uygulamalı. Sakarya: Sakarya Yayınc1lık.

Arseven, A. (2016). Öz yeterlik: Bir kavram analizi. Turkish Studies-International Periodical for the Languages, Literature and History of Turkish or Turkic, 11 (19), 6380.

Bala, I., Kaur, R. and Singh, S. (2017). Self-efficacy of senior secondary school students with respect to demographic variables. International Journal of Advanced Research and Development, 2 (4), 111-114.

Bandura, A. (1977). Self-efficacy toward a unifying theory of behavioral change. Psychological Review, 84 (2), 191-215.

Bandura, A. (1982). Self-efficacy mechanism in human agency. American Psychologist, 7 (2), 122-147.

Bandura, A. (1991). Social cognitive theory of self-regulation. Organizational Behavior and Human Decision Processes, 50, 248-287.

Bandura, A. (1997). Self-Efficacy: The Exercise of Control. New York, NY: W. H. Freeman and Company.

Bandura, A. (2012). Social Cognitive Theory. Handbook of Theories of Social Psychology. Thousand Oaks, CA: Sage Publications Ltd.

Bandura, A., Barbaranelli, C., Caprara, G. V. and Pastorelli, C. (1996). Multifaceted impact of self-efficacy beliefs on academic functioning. Child Development, 67, 1026-1222.

Barone, D., Maddux, J. E. and Snyder, C. R. (1997). Social Cognitive Psychology: History and Current Domains. New York: Plenum.

Boyd, N. G. and Vozikis, G. S. (1994). The influence of self-efficacy on the development of entrepreneurial intentions and actions. Entrepreneurship Theory and Practice, 18, 63-90.

Brown, L. J., Malouff, J. M. and Schutte, N. S. (2013). Self-Efficacy Theory (Chapter 2).

Bui, H. T., So, K. K. F., Kwek, A. and Rynne, J. (2017). The impacts of self-efficacy on academic performance: an investigation of domestic and international undergraduate students in hospitality and tourism. Journal of Hospitality, Leisure, Sport \& Tourism Education, 20, 47-54.

Capri, B., Özkendir, O. M., Özkurt, B. and Karakuş, F. (2012). General self-efficacy beliefs, life satisfaction and burnout of university students. Procedia-Social and Behavioral Sciences, 47, 968-973.

Carini, R. M., Kuh, G. D. and Klein, S. P. (2006). Student engagement and student learning: testing the linkages. Research in Higher Education, 47 (1), 1-32. 
Cassidy, S. and Eachus, P. (2002). The development of the general academic self efficacy scale (GASE). In Paper presented at the British Psychological Society Annual Conference, Blackpool, UK.

Charrow, C. B. (2006). Self-efficacy as a predictor of life satisfaction in older adults. Unpublished doctoral dissertation, The Adelphi University, New York.

Choi, N. (2005). Self-efficacy and self-concept as predictors of college students' academic performance. Psychology in the Schools, 42 (2), 197-205.

Coffman, D. L., \& Gilligan, T. D. (2002). Social support, stress, and self-efficacy: effects on students' satisfaction. College Student Retention, 4, 53-66.

Çokluk, Ö., Güçlü Ş. ve Şener B. (2010). Sosyal Bilimler İçin Çok Değişkenli İstatistik: SPSS ve Lisrel Uygulamalart. Ankara: Pegem Akademi.

Dahlke, L. M. (1992). Self-efficacy, career choice, and life satisfaction in college-educated women. Unpublished doctoral dissertation, The Marquette University, Milwaukee.

El-Hmoudova, D. (2015). Self-efficacy for learning vs ILS results in a group of english learning bachelor students. Procedia-Social and Behavioral Sciences, 199, 563-570.

Elias, S. M. and MacDonald, S. (2007). Using past performance, proxy efficacy, and academic self-efficacy to predict college performance. Journal of Applied Social Psychology, 37, 2518-2531.

Gecas, V. (1989). The social psychology of self-efficacy. Annual Review of Sociology, 15, 291-316.

Gist, M. E. (1987). Self-efficacy: implications for organizational behavior and human resource management. Academy of Management Review, 12 (3), 472-485.

Gist, M. E. and Mitchell, T. R. (1992). Self-efficacy: a theoretical analysis of its determinants and malleability. Academy of Management Review, 17 (2), 183-211.

Honicke, T. and Broadbent, J. (2016). The influence of academic self-efficacy on academic performance: a systematic review. Educational Research Review, 17, 63-84.

Joet, G., Usher, E. L. and Bressoux, P. (2011). Sources of self-efficacy: an investigation of elementary school students in France. Journal of Educational Psychology, 103, 649-663.

Jung, K. R., Zhou, A. Q. and Lee, R. M. (2017). Self-efficacy, self-discipline and academic performance: Testing a contextspecific mediation model. Learning and Individual Differences, 60, 33-39.

Komarraju, M. and Nadler, D. (2013). Self-efficacy and academic achievement: why do implicit beliefs, goals, and effort regulation matter?. Learning and Individual Differences, 25, 67-72.

Lane, A. M., Hall, R. and Lane, J. (2004). Self-efficacy and statistics performance among sport studies students. Teaching in Higher Education, 9 (4), 435-461.

Lent, R. W. and Hackett, G. (1987). Career self-efficacy: empirical status and future directions. Journal of Vocational Behavior, 30, 347-382.

Maddux, J. E. (2000). Self-Efficacy: The Power of Believing You Can. (Edt. Snyder, C. R. and Lopez, S. J.). Handbook of Positive Psychology. New York: Oxford University Press.

Neuville, S., Frenay, M. and Bourgeois, E. (2007). Task value, self-efficacy and goal orientations: impact on self-regulated learning, choice and performance among university students. Psychologica Belgica, 47, 95-117.

Pintrich, P. R. and De Groot, E. V. (1990). Motivational and self-regulated learning components of classroom academic performance. Journal of Educational Psychology, 82, $33-40$. 
Kızanlıklı ve Silik / Turizm Eğitimi Alan Lisans Öğrencilerinin Öz Yeterliklerinin Akademik Başarı ve

Bireysel Özellikler Açısından İncelenmesi / Examination of the Self-Efficacy of Undergraduate Students in Tourism Education in terms of Academic Achievement and Individual Characteristics

Robbins, S. B., Lauver, K., Le, H., Davis, D., Langley, R., and Carlstrom, A. (2004). Do psychosocial and study skill factors predict college out-comes? A metaanalysis. Psychological Bulletin, 130, 261-288.

Roick, J. and Ringeisen, T. (2017). Self-efficacy, test anxiety, and academic success: a longitudinal validation. International Journal of Educational Research, 83, 84-93.

Ryan, T. R. (1970). Intentional Behavior: An Approach to Human Motivation. New York: The Ronald Press Company.

Schunk, D. H. (1989). Self-efficacy and cognitive achievement: implications for students with learning problems. Journal of Learning Disabilities, 22, 14-22.

Schunk, D. H. and Pajares, F. (2002). The Development of Academic Self-Efficacy. Development of Achievement Motivation. San Diego, CA, US: Academic Press.

Schwarzer, R. (1998). Optimism, goals, and threats: how to conceptualize self-regulatory processes in the adoption and maintenance of health behaviors. Psychology \& Health, 13, 759-766.

Schwarzer, R. (2001). Social-cognitive factors in changing health-related behavior. Current Directions in Psychological Science, 10, 47-51.

Sevilmiş, A. ve Şirin, E. F. (2016). Spor bilimleri fakültesi öğrencilerinde akademik başarı: üniversite yaşam kalitesi, akademik güdülenme ve akademik öz yeterliğin rolü. Ankara Üniversitesi Spor Bilimleri Fakültesi Spormetre Dergisi, 14 (1), 31-44.

Stumpf, S. A.. Brief, A. P. and Hartman, K. (1987). Self-efficacy expectations and coping with career related events. Journal of Vocational Behavior, 31, 91-108.

Talsma, K., Schüz, B., Schwarzer, R. and Norris, K. (2018). I believe, therefore i achieve (and vice versa): a meta-analytic cross-lagged panel analysis of self-efficacy and academic performance. Learning and Individual Differences, 61, 136-150.

Tong, Y. and Song, S. (2004). A study on general self-efficacy and subjective well-being of low ses college students in a Chinese university. College Student Journal, 38 (4), $637-$ 647.

Tsai, C. T., Hsu, H. and Yang, C. C. (2017). Career decision self-efficacy plays a crucial role in hospitality undergraduates' internship efficacy and career preparation. Journal of Hospitality, Leisure, Sport \& Tourism Education, 21, 61-68.

Wood, R. and Bandura, A. (1989). Social cognitive theory of organizational management. Academy of Managemenl Review, 14 (3), 361-384.

Ural, A. ve İbrahim, K. (2013). Bilimsel Araştırma Süreci ve SPSS ile Veri Analizi. (4. Baskl). Ankara: Detay Yayıncilik.

Yamane, T. (2001). Temel Örnekleme Yöntemleri (1. Baskı). (Çev. A. Esin, M. A. Bakır, C. Aydın ve E. Gürbüzsel). İstanbul: Literatür Yayıncılık.

Yeşilyurt, E., Ulaş, A. H. ve Akan, D. (2016). Teacher self-efficacy, academic self-efficacy and computer self-efficacy as predictors of attitude toward applying computer-supported education. Computers in Human Behavior, 64, 591-601.

Yılmaz, E., Yiğit, R. ve Kaşarcı, İ. (2012). İlköğretim öğrencilerinin öz yeterlik düzeylerinin akademik başarı ve bazı değişkinler açısından incelenmesi. Mehmet Akif Ersoy Üniversitesi Ĕ̈itim Fakültesi Dergisi, 23, 371-388.

Zimmerman, B. J. and Martinez-Pons, M. (1990). Student differences in self-regulated learning: relating grade, sex and giftedness to self-efficacy strategy use. Journal of Educational Psychology, 82, 51-59. 